原著

\title{
低温酸素プラズマ扊化応用による生物 試料中フッ素の測定*
}

\author{
富田美佐子** 鈴 木衆 - ${ }^{* *}$ 黒岩 茂** \\ 金 子 芳 洋**
}

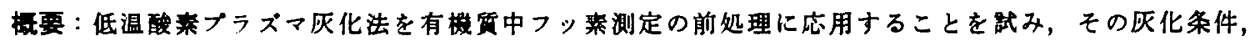
固定郕添加の必要性およびその選択などを血消・血椞を用いて検时ナるとともに，その他の生物試料へ の応用の可能性も検时した。

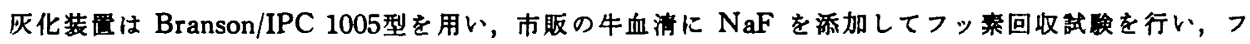

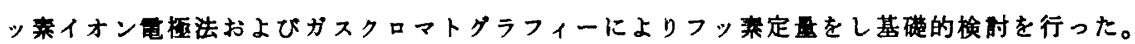

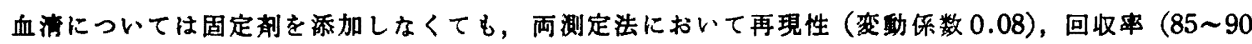
\%)ともに良好な結果が得られた。しかし NBS 標淮試料（orchard leaves, oyster tissue）のフッ菜測定 結果は，NBS 参考值に対して好成繶を示したが，固体試料にっいては，低温灰化時にも，固定都添加の 必要性が判明した。

さらにラットを用いてフッ秦の飲用実験を行い，その血墏中フッ秦を ionizable F と total Fに分け前 記と同様な方法で测定したところ, 両者は高い相関（r>0.95）を示した。また ionizable $F$ と total $F$ の 比はフッ秦イオン電極法で0.73 0.89, GC 法で0.59 0.73となったが,フッ素投与群では対照群に比へ ionizable F の割合が增加していることが詪められた $(\mathrm{P}<0.05) 。$

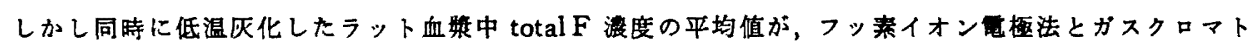

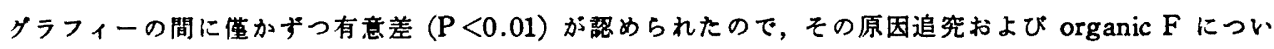

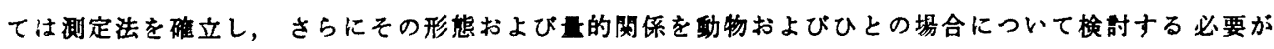
ある。

索引用語 : フッ素, 生物試料, 血液, 低温灰化, ガスクロマトグラフィー

\section{はじめに}

近年, 血液（血清および血漿）中フッ素（以下 Fとす る）灌度は，尿中 F 旅度とともに，歯学の分野において も生物学的指標の一つとしてその重要性の認識が高ま り, 埴料水中および歯牙中の $\mathrm{F}$ 浱度, 加此命との関係など について検討され，微量測定が行われている1-8)。

また, 1968 年に Taves ${ }^{9,10)}$ が血清中Fには遊雄型 (free, exchangeable) と結合型 (bound, non-exchangeable) の 2 種が存在することを発表して以来, Ophaug と Singer 11-14), Venkateswarlu15-17), Patterson 5 ${ }^{18)}$,

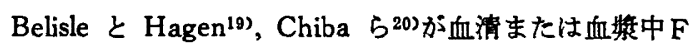
を ionizable F と total F に分けて測定し, その存在様 式および濃度について報告している。

しかし，血液中Fの様態については，Taves',10)の血 鼎中アルブミンヘの 結合説, Ekstrand ら21)のそれに対

* 本論文の要旨は第 31 回日本口腔衛生学会総会 (昭和57年 9 月) おょび第53回日本衛生学会総会（昭和58年 4 月） において発表した。

** 昭和大学歯学部口腔街生学教室（主任：金子芳洋教投）

* Department of Hygiene and Oral Health, School of Dentistry, Showa University (Chief: Prof. Yoshihiro KANEKO)

昭和58年 5 月 17 日受付 
する反論に代表されるごとく，いまだ充分に解明されて いないのが現状である。この様な領域においては, とく に低濃度レベルでのより精度が高く再現性のよい定量法 の確立が不可欠である。

多有機質中微量 Fの湘定は，(1) 前処理としてその妨 害物質からの分離法，（2）精度および感度の高い測定 法, の両面から検郡がなされている。(1) については, 従来からの水蒸気蒸留法またはマッフル炬による乾性灰 化が-・般的で，微量拡散法が併用される場合が多い。さ らに，近年では白金内張り酸素ボンブ法14,17,19)，化学的

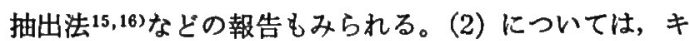
レートによる 比色法に代り, フッ素選択性イオン電極 (fluoride ion-specific electrode, 以下イオン電極とする) 法1-9)が一般に使用されているが，ガスクロマトグラフ ィー22,28) (以下 GC 法と略す), 前処理を必要としない フッ化アルミニウムによる分子吸光法20,24,25) (以下 AIF 法と略す) などが愉即されつつある。

今回著者らは, 前処理法として低温酸素プラズマ灰化 の応用を試みた。これは従来のマッフル炉による乾性灰 化が，灰化時におこる $\mathrm{F}$ の減失や污染のため，または固 定剤からのFのため良好な回収率が得られていないなど の問題点があるからである26,27)。

低温酸素 プラズマ灰化（以下低温灰化法，または単 に灰化法と略す）は高周波エネルギーで原子状酸素を 生成させて, 試料を酸化する方法であり，比較的低温

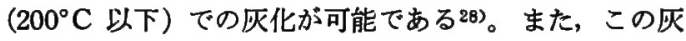
化法は分解試薬を必要としないことから，Chester ら ${ }^{299}$ が血液に $\mathrm{As}, \mathrm{Cr}, \mathrm{Pb}, \mathrm{Se}, \mathrm{Sb}$ などを添加して行った 回収試験結果は良好であったと報告している。

そこでこの低温灰化法を $\mathrm{F}$ 分析の前処理に応用し，ま ず灰化条件および固定剤の有無との関保を牛血清を用い て検討しその有用性を確認した。なお，Fの測定はイオ

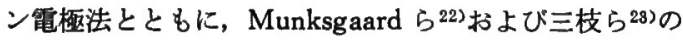
GC 法を改良して実施した。

さらにラットを用いて短期 $\mathrm{F}$ 投与（欬用）実験を行

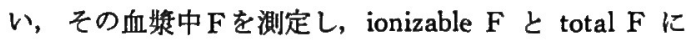
ついて若干の知見を得たので合わせて報告する。

\section{方 法}

\section{1 装置, 器具, 試薬および実験動物}

\section{1 .1 装置}

(1) 低温酸素プラズマ兏化装置

(Branson/IPC 1005-248AN low temperature asher)

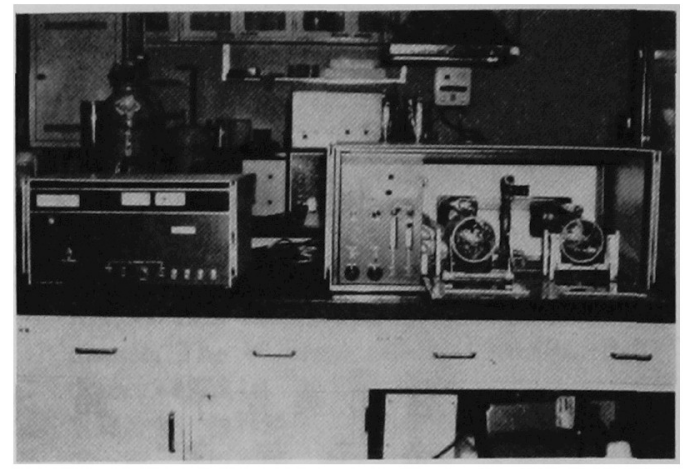

Fig. 1 Branson/IPC 1005-248AN low temperature asher

(2) ガスクロマトグラフ(島津 GC-7AG, FID 付)

(3) イオンメータ(Orion research, microprocessor ionalyzer Model 901)

(4) F選択性イオン電極 (Orion research, Model 96-09 combination fluoride electrode)

(5) 遠心分離機（久保田, KN-70）

2.1 .2 器具

(1) マイクロシリンジ $(10 \mu l)$

(2) マイクロピペット $(0.1 \sim 1 \mathrm{~m} l$ 用各種)

(3) ポリプロピレン製共栓試験管 $(10 \mathrm{~m} l$ 容量)

(4) プラスチック 製共栓スピッッ管 ( $2 \mathrm{ml}$ 容量)

(5) パイレックスガラス製灰化ボート（直径 $40 \mathrm{~mm}$, 深さ $10 \mathrm{~mm}$ )

(6) プラスチック製小型容器 $(1 \sim 2 \mathrm{~m} l$ 容量 $)$

2.1 .3 試藥

(1) 塩酸 ( $\mathrm{HCl})$ （有害金属測定用, 和光純薬)

(2) $\mathrm{n}$-ヘキサン $\left(\mathrm{C}_{6} \mathrm{H}_{16}\right)$ (残留農楽測定用, 和光純 薬)

(3) Trimethyl chlorosilane $\left[\left(\mathrm{CH}_{3}\right)_{3} \mathrm{SiCl}\right.$, 以下 TMCS と略す了(東京化成)

(4) Total ionic strength adjustor (TISAB III, Orion research Cat. No. 9409-11)

(5) $\mathrm{F}$ 標準液 $100 \mathrm{ppm}$ の $\mathrm{F}$ 標集液 (Orion research Cat. No. 94-09-07）を用時, 1 おょび 0.1ppmに 希䣋調製した。

(6) 固定鼡 : 水酸化マグネシウム $\left[\mathrm{Mg}(\mathrm{OH})_{2}\right]$, 水酸化カルシウム $\left[\mathrm{Ca}(\mathrm{OH})_{2}\right]$, 水酸化ストロ ンチウム $\left[\mathrm{Sr}(\mathrm{OH})_{2}\right]$ （いずれも試薬特級，和 光純薬)

2.1.4 標準試料と血清・血漿試料 
(1) NBS* standard reference material

Orchard leaves (No. 1571)

Oyster tissue (No. 1566)

(2) 血清: New born calf serum(Irvine scientific)

(3) 血 $\mathrm{NaF}$ 溶液飲用 $\mathrm{SD}$ ラットより採血した もの。

* NBS : National Bureau of Standards

\subsection{5 実験動物}

SD 系ラット（雄，10週龄）を各群 12 匹, 合計 48 匹 を使用した。飼料はオリェンタル社䌘の MF（Fを約 $35 \mathrm{ppm}$ 含む) を自由掞取させた。

\section{2 前処理および測定法}

\section{2 .1 固定郕の精製}

本実験で使用した固定剤 $\mathrm{MgCl}_{2}, \mathrm{CaCl}_{2}$ および $\mathrm{SrCl}_{2}$ はまず各々の水酸化物約 $50 \mathrm{~g}$ に $20 \% \mathrm{HCl}$ 溶液を加えて $\mathrm{pH}$ を 1 以下とした後， $20 \%$ TMCS n-hexane 溶液 $5 \mathrm{~m} l$ を加えて 40 分間振とうした。静圈後 $\mathrm{n}$-hexane 層 を搭て，同様な操作をさらに5回綵返して行い脱 $\mathrm{F} し$ た。ついで，残りの水層に過剩の水酸化ナトリウム $(\mathrm{NaOH})$ を加え各金属の水酸化物を沈筑させ，遠心分 離後水層を除去した。沈筑物を乾燥後, $\mathrm{Mg}(\mathrm{OH})_{2}$ $5.8 \mathrm{~g}, \mathrm{Ca}(\mathrm{OH})_{2} 7.4 \mathrm{~g}, \mathrm{Sr}(\mathrm{OH})_{2} 12.2 \mathrm{~g}$ を $\mathrm{HCl}$ で中和 し, 約 $\mathrm{pH} 6$ に調製した。この溶液に蒸留水を加えて $100 \mathrm{~m} l$ とし，低温灰化用固定剤溶液とした。

\section{$2.2 .2 \mathrm{GC}$ 条件}

カラム : 15\%OV-101, Chromosorb W. AW.

DMCS, $3.0 \mathrm{~mm} \times 1.5 \mathrm{~m}$ ガラス

温度: カラム $-70^{\circ} \mathrm{C}$ ( 2 分) $230^{\circ} \mathrm{C}(1$ 分)* 検

出器 $-130^{\circ} \mathrm{C}$

ガス流量 : He, $35 \mathrm{~m} l / \mathrm{min}$

$\mathrm{H}_{2}, 0.5 \mathrm{~kg} / \mathrm{cm}^{2}$

Air, $0.5 \mathrm{~kg} / \mathrm{cm}^{2}$

検出器: Flame ionization detector (以下 FID と 略す)

感 度: Attenuation, 1, Range, 1

*: 溶媒の流出を早め, 次の試料注入を早くするた め昇温する。

\subsubsection{GC 法による血清・血墏中 $F$ 測定}

血清および血漿中 $\mathrm{F}$ 搌度測定は, 前処理として低温灰

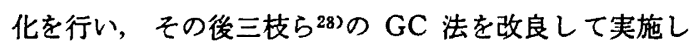
た。前処理の概要は Fig. 2 に示した。

血清または血漿 $2 \mathrm{~m} l$ をパイレックスガラス 製灰化ボ 一トにとり, 蒸留水 $1 \mathrm{~m} l$ を加えて 凍結乾燥（所要時間 は約 2 時間) した後, 出力 $100 \mathrm{~W}$, 酸素流量 $100 \mathrm{~m} l / \mathrm{min}$,

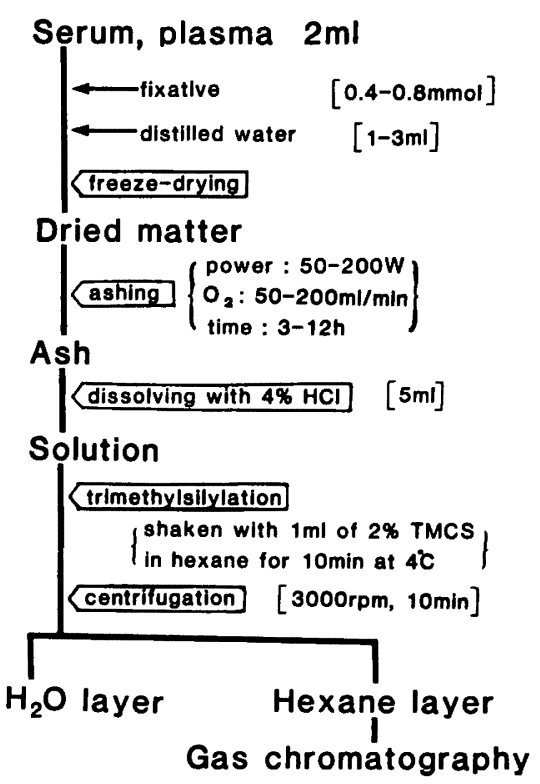

Fig. 2 The analytical procedure for measurement of total $F$ in serum and plasma

$4 \sim 5$ 時間で灭化した。灰化物を $4 \% \mathrm{HCl}$ 水溶液 $5 \mathrm{ml}$ で溶解し, 容量 $10 \mathrm{~m} l$ のプラスチック 製共栓試耠管に移 した。 $4^{\circ} \mathrm{C}$ の低温下で, これに $2 \%$ TMCS n-haxane 溶液 $1.0 \mathrm{~m} l$ を加えて10分間振と らし, $\mathrm{F}$ t trimethyl fluorosilane $\left[\left(\mathrm{CH}_{3}\right)_{3} \mathrm{SiF}\right.$, 以下 TMFS と略す)に誘 導した。この試験管を $3000 \mathrm{rpm} て ゙ 10$ 分間遠心分離し, $\mathrm{n}$-haxane 層を容量 $2 \mathrm{~m} l$ のプラスチック 製共栓小型ス ピッツ管にとり，その $2 \sim 3 \mu l$ を GC に注入してFを 測定した。

定量は $4 \% \mathrm{HCl}$ 水溶液 $4 \mathrm{~m} l$ にF 標準液 $(0.05$, $0.25,0.5,1.0 \mathrm{ppm})$ を $1 \mathrm{~m} l$ 加え, 試料と同様 TMFS 化後に検量線を作成し，絶対検量線法により行った。

\subsection{4 イオン電極法による血清・血娽中 $\mathrm{F}$ 測定}

\section{a) 無灰化試料}

血清または血漿 $1 \mathrm{~m} l$ をプラスチック 䌘小型容器にと り, 蒸留水 $1 \mathrm{~m} l$ と TISAB III $0.2 \mathrm{~m} l$ を添加し, 10 分 問挠拌後常法によりイオン電極で $\mathrm{F}$ 懐度を測定した。 $\mathrm{F}$

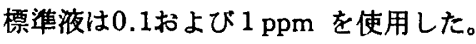

b) 灰化試料

低温灰化した血清または血䈋試料が入っている灰化ボ 一トに, 蒸留水 $2 \mathrm{~m} l$ と TISAB III $0.2 \mathrm{~m} l$ を直接添加 して灰化物を完全に溶解させた。この溶液をイオン電極 測定用のプラスチック 製小型容器に移し, 10 分間観拌 後, 無灰化試料と同様に常法によりイオン電極で $\mathrm{F}$ 濃度 
を測定した。

\section{3 測定法の㭘讨}

\subsection{1 灰化条件}

a) 固定剤の選択

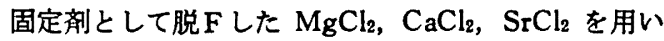

て，低温灰化時に扔ける $\mathrm{F}$ 固定効果を検討した。

牛血清 $2 \mathrm{~m} l$ に 標準液 $(1 \mathrm{ppm}) 1 \mathrm{ml}$ (Fとして $1 \mu \mathrm{g})$ と固定剤溶液（ $1 \mathrm{~mol} / l) \quad 0.8 \mathrm{~m} l$ を添加して凍結 乾燥を行い, 出力 $200 \mathrm{~W}$, 酸秦流 $200 \mathrm{ml} / \mathrm{min}$ で 12 時間 灰化した。固定剈として $\mathrm{MgCl}_{2}, \mathrm{CaCl}_{2}, \mathrm{SrCl}_{2}$ を用い た場合について，それぞれのF回収率を比較し固定剤の 効果を判定した。

b) 灰化条件の選択

低温灰化装置の条件設定においては，出力，酸素流 量，灰化時間を灰化試料量およびその性状にあわせて選 択することが必要である。

F $1 \mu \mathrm{g}$ 添加牛血清を用い，出力および酸素流量はつ ぎの 3 種の組合せ一 $50 \mathrm{~W} \cdot 50 \mathrm{~m} l / \mathrm{min}, 100 \mathrm{~W} \cdot 100 \mathrm{~m} /$ $\mathrm{min}, 200 \mathrm{~W} \cdot 200 \mathrm{ml} / \mathrm{min}$, 灰化時間はそれぞれ 3 ， 6，12時間に設定した。その灰化物を GC 法でF測定 し，回収率を求め最適条件を検討した。

\subsection{2 測定法の比較}

牛血清 $1.5 \mathrm{~m} l$ に $\mathrm{NaF}$ 水溶液を $\mathrm{F}$ として $1.0 \mu \mathrm{g}$ 添加 して, 無灰化一イオン電極法, 扊化一イオン電極法, 扊 化一GC 法, 固定剂添加による灰化-GC 法の 4 種の测 定法によるF回収試験を行った。測定は各 6 回綝返し行 い, 回収率の平均値 と標準偏差（以下 SD と略す）を 求めて測定法を比較した。

なお固定斉は $\mathrm{SrCl}_{2}$ 水溶液 $(1 \mathrm{~mol} / l) 0.4 \mathrm{ml}$ を添加

し，その灰化時間は12〜15時間とした。

\subsubsection{NBS 標準試料の灰化およびF 測定}

NBS 標準試料のうち, 植物性試料として orchard leaves, 動物性試料として oyster tissue を固定剤添加お
よび無添加で低温灰化し，ついで GC 法によるF 测定 を行い NBS の分析参考值 (non-certified value) と比 較した。試料量はそれぞれ $0.5 \mathrm{~g}$ ，固定剂として $1 \mathrm{~mol} / l$ の $\mathrm{MgCl}_{2}, \mathrm{CaCl}_{2}, \mathrm{SrCl}_{9}$ 水溶液 $0.8 \mathrm{~m} l$ を添加し, さら に蒸留水 $3 \mathrm{ml}$ を加え, 凍結乾燥した後, 出力 $200 \mathrm{~W}$, 酸素流 $200 \mathrm{~m} / / \mathrm{min}$ で15時間灰化した。

\section{4 ラットによる F 飲用実稂}

\subsubsection{F 飲用実験}

SD 系ラットを 1 群 12 匹で, 対照（水道水埴用, F : $0.1 \sim 0.2 \mathrm{ppm}) ， 50,100,200 \mathrm{ppm} \mathrm{F}$ 飲用の 4 群に分 け，10日間 $\mathrm{F}$ 溶液（ $\mathrm{NaF}$ 溶液）を自由摄取させ，その 後エーテル麻酔下で腹部下行大县脈より採血した。直ち にヘパリン処理し血漿を分離した。

\subsection{2 ラットの血墏中 F 測定}

分離した血墏をイオン電極測定用試料 $(1 \mathrm{ml})$ と兏化 用試料 (GC 用, イオン電極用各 $2 \mathrm{~m} l$ ) に分け, 直ち にイオン電極測定を行い，まず ionizable F を求めた。 灰化用試料は冷凍保存し, 順次灰化を行い, GC とイオ ン電極で測定し血漿中の total F 浱度を求めた。 つぎにその測定值から各群の血墏中 $\mathrm{F}$ 浱度の平均值と $\mathrm{SD}$, ionizable $\mathrm{F}$ と total $\mathrm{F}$ の相関およびその比率を検 討した。

\section{結 果}

\section{1 灰化条件の検讨}

\section{1 .1 固定斉添加の場合}

$\mathrm{F}$ 添加牛血清に固定剤を加え低温灰化を行い， $\mathrm{F}$ 回収 率を求めた成績を Table 1 に示した。

$\mathrm{MgCl}_{2}$ および $\mathrm{CaCl}_{2}$ の添加は灰化不良をもたらし， 良好な回収率が得られなかった。しかし $\mathrm{SrCl}_{2}$ 添加の場 合は良好に灰化され，平均 $94 \%$ の回収率が得られた。比 較のために行った同灰化条件における固定剂無添加の場 合の回収率は78\%であった。このことから血清の低温灰

Table 1 Effectiveness of fixative addition*

\begin{tabular}{ccccc}
\hline Fixatives & $\begin{array}{c}\text { Fadded (as NaF) } \\
(\mu \mathrm{g})\end{array}$ & \multicolumn{3}{c}{ Recovery rate $(\%)$} \\
\cline { 3 - 5 } & 1.0 & Found & Mean & $\pm \mathrm{SD}$ \\
\hline $\mathrm{MgCl}_{2}$ & 1.0 & $* *$ & & \\
$\mathrm{CaCl}_{2}$ & 1.0 & $95,96,92,92$ & 94 & 1.8 \\
$\mathrm{SrCl}_{2}$ & 1.0 & $79,79,76,77$ & 78 & 1.3 \\
None & & & & \\
\hline
\end{tabular}

* Two milliliters of calf serum were used for each experiment. Electric power 200W, oxygen $200 \mathrm{ml} / \mathrm{min}$, ashing for $12 \mathrm{hrs}$.

** Enough ashing for the determination of $F$ was not obtained. 
Table 2 Recovery of $\mathrm{F}$ under various ashing conditions*

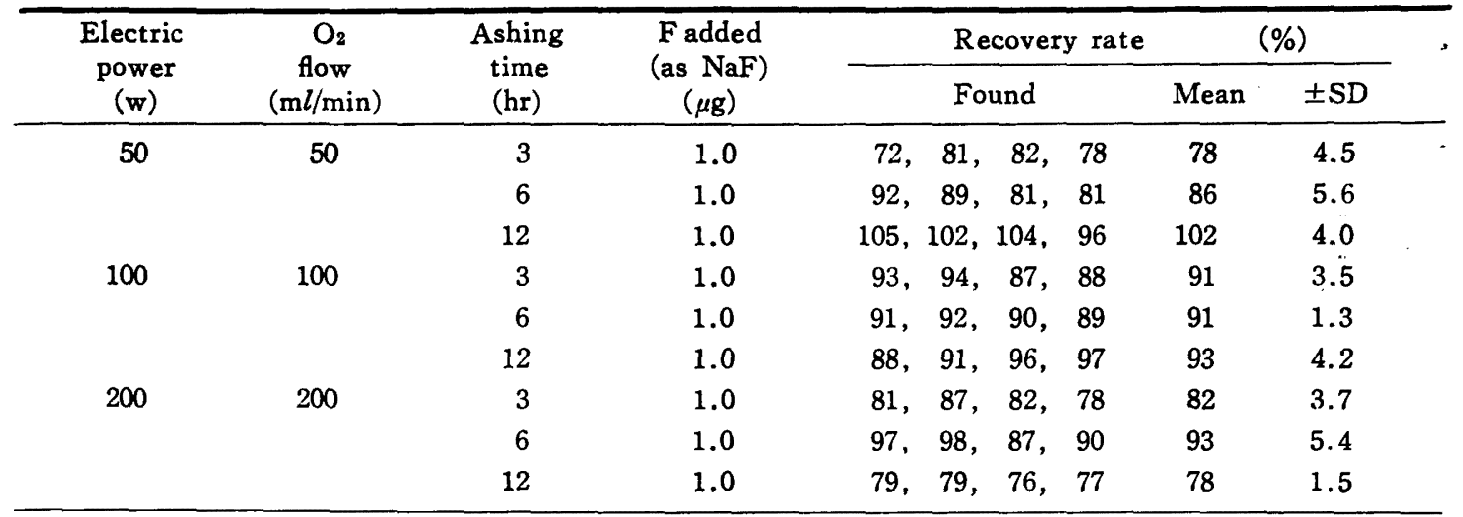

* Two milliliters of calf serum were used for each experiment, and no fixatives were added for ashing.

化では固定郕を添加しなくても相当な回収事が得られる ことが示唆され，以後主として固定剤無添加の条件につ いて検討を進めた。

\section{1 .2 固定郕無添加の場合}

固定剂無添加で行った各種の低温灭化条件における F 添加牛血清の回收武酫成綪を Table 2 に示した。

$\mathrm{NaF} （ \mathrm{~F}$ として $1 \mu \mathrm{g}$ ）添加牛血清では，50，100，

(a) Standard (b) Standard (c) Calf serum (d) F-added

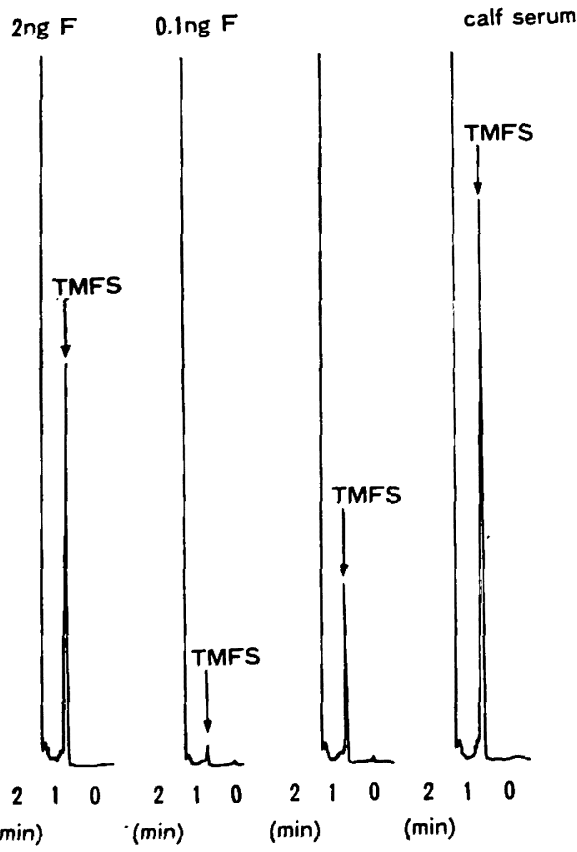

Fig. 3 Gas chromatograms of trimethyl fluorosilane (TMFS)

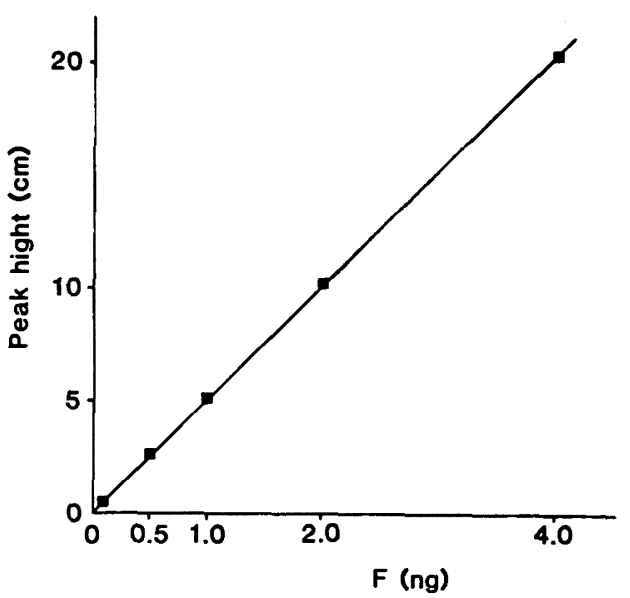

Fig. 4 A standard curve for $F$ determination from trimethyl fluorosilane

200W いずれの灰化出力でも適切な㚒化時間を選択する ことにより，高い回収率が得られた。とくに100W では 3 〜 12時間の灰化でいずれも $90 \%$ 以上の安定した回收率 が得られたので, 本実験では $100 \mathrm{~W} \cdot 100 \mathrm{~m} l / \mathrm{min}, 4 \sim 6$ 時間で血清抽よび血墏の灰化を行った。

\section{$3.2 \mathrm{GC}$ 法の検时}

\section{2 .1 ガスクロマトグラム}

前記 (2.2.2項) の条件で測定した TMFS 誘導化 後の $\mathrm{F}$ 標準液と牛血清武料の実際のクロマトグラムを Fig. 3 に示した。

\section{2 .2 検量線}

$F$ 標準液 $0.05,0.25,0.5,1.0 \mathrm{ppm}$ を試料と同様 TMFS に誘導化後，GC に注入し作成した検量線を Fig. 4 亿示した。 
Table 3 Detection limits of $F$ contents in calf serum and orchard leaves in different analytical methods

\begin{tabular}{lllcc}
\hline \multicolumn{2}{c}{$\begin{array}{c}\text { Sample } \\
(\mathrm{m} l)\end{array}$} & \multicolumn{1}{c}{$\begin{array}{c}\text { Analytical } \\
\text { method }\end{array}$} & $\begin{array}{c}\text { GC injection } \\
\text { volume }(\mu l)\end{array}$ & $\begin{array}{c}\text { Detection } \\
\text { limit }(\mu \mathrm{g} / \mathrm{m} l)\end{array}$ \\
\hline Calf serum & $0.5 \sim 1$ & No ashing-ion electrode & - & 0.02 \\
Calf serum & 2 & Ashing-ion electrode & - & 0.02 \\
Calf serum & 2 & Ashing-GC & 3 & 0.015 \\
Orchard leaves & $0.5^{*}$ & Ashing-GC & 3 & $0.06^{* *}$ \\
\hline
\end{tabular}

* (g)

** $(\mu \mathrm{g} / \mathrm{g})$

Table 4 Recovery in four different analytical methods

\begin{tabular}{|c|c|c|c|c|c|}
\hline \multirow{4}{*}{ Method } & \multicolumn{5}{|c|}{$(\mu \mathrm{g} / \mathrm{m} l$ serum $)$} \\
\hline & \multirow[t]{2}{*}{ Added } & \multicolumn{2}{|c|}{ Found } & \multicolumn{2}{|c|}{ Recovery } \\
\hline & & Mean & $\pm \mathrm{SD}$ & Mean & $\pm \mathrm{SD}$ \\
\hline & $(\mu \mathrm{g})$ & $(\mu g)$ & $(n=6)$ & \multicolumn{2}{|c|}{$(\%)$} \\
\hline Ion electrode & $\left\{\begin{array}{c}- \\
1.0\end{array}\right.$ & $\begin{array}{l}0.192 \\
1.176\end{array}$ & $\begin{array}{l}0.007 \\
0.006\end{array}$ & 98.4 & 0.6 \\
\hline Ashing-ion electrode & $\left\{\begin{array}{c}- \\
1.0\end{array}\right.$ & $\begin{array}{l}0.224 \\
1.132\end{array}$ & $\begin{array}{l}0.009 \\
0.023\end{array}$ & 90.8 & 2.3 \\
\hline Ashing-GC & $\left\{\begin{array}{c}- \\
1.0\end{array}\right.$ & $\begin{array}{l}0.235 \\
1.080\end{array}$ & $\begin{array}{l}0.015 \\
0.067\end{array}$ & 84.5 & 6.7 \\
\hline $\mathrm{SrCl}_{2}$ *ashing-GC & - & $\begin{array}{l}0.220 \\
1.041\end{array}$ & $\begin{array}{l}0.023 \\
0.052\end{array}$ & 83.8 & 6.8 \\
\hline
\end{tabular}

* Ashing with a fixative, $\mathrm{SrCl}_{2}$

Table $5 \mathrm{~F}$ content found in animal and vegetable matters with the non-certified values by NBS in cases of ashing with or without fixatives

\begin{tabular}{|c|c|c|c|c|c|c|c|}
\hline \multirow{2}{*}{ Sample } & \multirow{2}{*}{\multicolumn{2}{|c|}{$\begin{array}{c}\text { Fixative } \\
(0.8 \mathrm{mmol})\end{array}$}} & \multicolumn{3}{|c|}{ Content } & \multirow[b]{2}{*}{ Mean } & \multirow[b]{2}{*}{$\pm \mathrm{SD}$} \\
\hline & & & Fo & & & & \\
\hline \multirow[t]{5}{*}{ Oyster tissue } & $\mathrm{MgCl}_{2}$ & 6.6 & 5.9, & 5.2, & 5.5 & 5.8 & 0.60 \\
\hline & $\mathrm{CaCl}_{2}$ & 4.4 & 5.0 & 5.0 & 4.7 & 4.8 & 0.29 \\
\hline & $\mathrm{SrCl}_{2}$ & 5.0 & 4.2 , & 4.2 , & 4.7 & 4.6 & 0.39 \\
\hline & None & 0.4 & 0.4 & 0.4 , & 0.3 & 0.4 & -- \\
\hline & \multicolumn{5}{|c|}{ Non-certified value given by NBS } & 5.2 & - \\
\hline \multirow[t]{5}{*}{ Orchard leaves } & $\mathrm{MgCl}_{2}$ & 3.6 & 3.7 & 3.6, & 3.9 & 3.7 & 0.12 \\
\hline & $\mathrm{CaCl}_{2}$ & 3.4 & 3.4 & 3.3 , & 3.7 & 3.5 & 0.17 \\
\hline & $\mathrm{SrCl}_{2}$ & 4.0 & 3.9 & 3.8, & 4.4 & 4.0 & 0.26 \\
\hline & None & 4.2 & 4.2 & 4.3, & 4.3 & 4.3 & 0.06 \\
\hline & \multicolumn{5}{|c|}{ Non-certified value given by NBS } & 4 & - \\
\hline
\end{tabular}

Sample weight for each experiment: $0.5 \mathrm{~g}$

\section{2 .3 検出限界}

$\mathrm{GC}$ 法における最小検出量は, クロマトグラム上 $5 \mathrm{~mm}$ を最小検出ピーク高とすると，Fとして0.1ng
に相当した。なお固定阂中の F は最小検出量の 1/10 以下

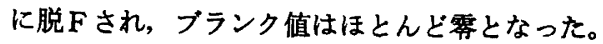
液体試料および固体試料の F検出限界を, イオン電極 


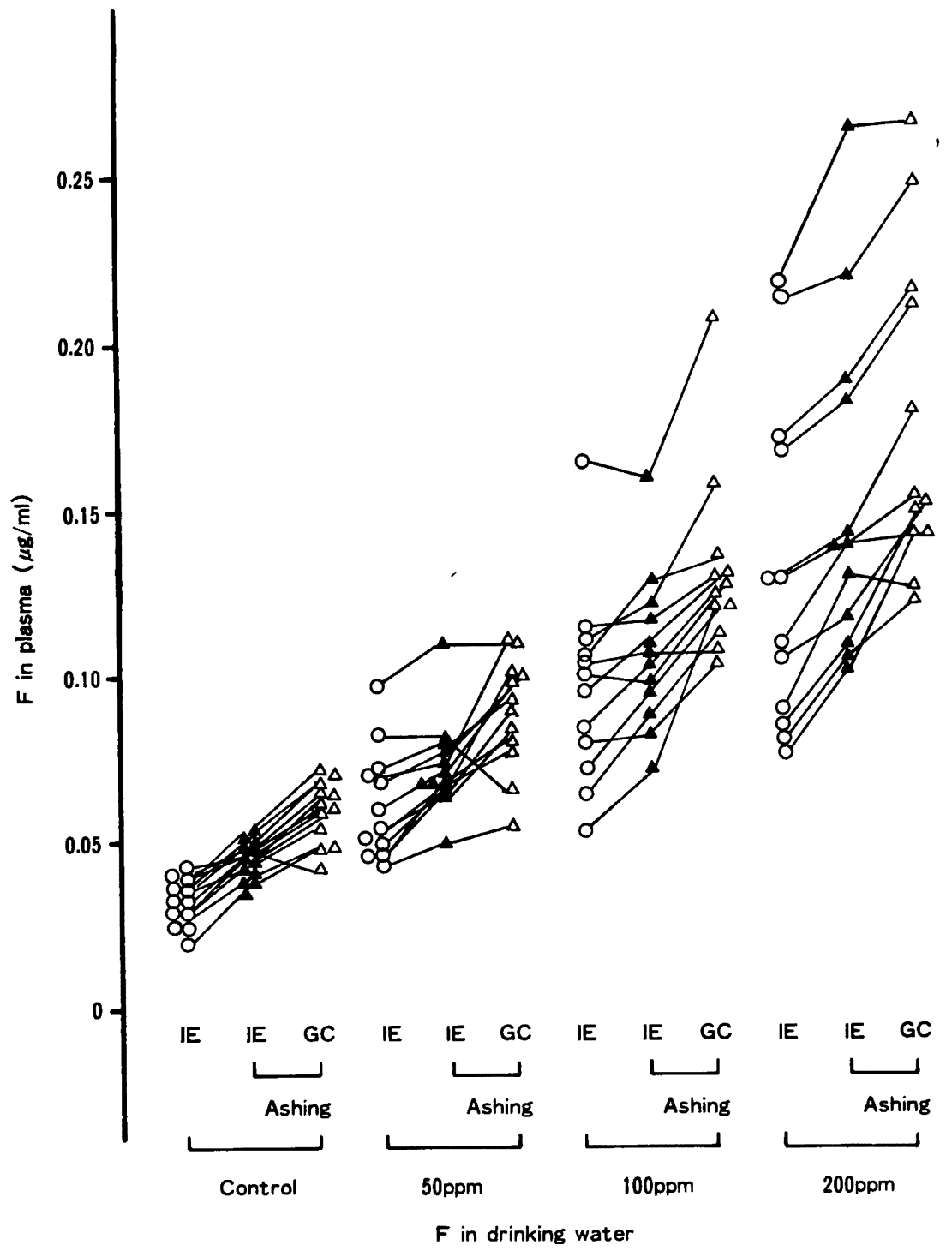

Fig. 5 F content in rat plasma determined by different analytical methods IE : F ion electrode measurement. GC: Gas chromatography analysis.

法の場合と合せて Table 3 に示した。GC 法は試料量 $2 \mathrm{~m} l$ の血清では $\mathrm{F}$ として $0.015 \mu \mathrm{g} / \mathrm{m} l$ となり, イオン 電極法の $0.02 \mu \mathrm{g} / \mathrm{m} l$ と殆ど同レベルであった。しかし GC 法は TMFS へのシリル化時に, TMCS n-hexane 溶液量を減ずると，F が滣縮され，また GC へ の注入量も増量 $(6 \sim 8 \mu l)$ できる余裕があり,これ以 上の感度向上も可能である。

\section{3 測定法の比较}

F 添加牛血清を用いて行った異る 4 測定法によるF回 収試酚成績を Table 4 亿示した。

無戻化一イオン電極法は $\mathrm{F}$ 標準夜を血清に添加しただ けであるが，有機所への新たな結合，マトリックスの相 䢖などにより回収率の低下も推定された。しかし結果は 回収率 $98.4 \%$, 変動係数（以下 $\mathrm{CV}$ と略す）も 0.01 以 内となった。

灰化操作を行った他の 3 方法では，回收率はいずれも 
Table $6 \mathrm{~F}$ content in plasma of rats given drinking water with different $\mathrm{F}$ concentrations determined by different analytic methods

\begin{tabular}{|c|c|c|c|c|c|}
\hline \multirow{2}{*}{$\begin{array}{l}\text { Animal } \\
\text { group }\end{array}$} & \multirow{2}{*}{ Method } & \multicolumn{2}{|c|}{$F$ in plasma $(\mu \mathrm{g} / \mathrm{m} l)$} & & \\
\hline & & Mean & $\pm S D(n=12)$ & & \\
\hline & $\Gamma^{I E^{a)}}$ & 0.035 & 0.007 & & \\
\hline Control & Ashing $-I^{\text {a) }}$ & 0.047 & 0.005 & $\left.* *^{c}\right)$ & \\
\hline & $L_{\text {Ashing-GC }}$ & 0.059 & 0.008 & & $* c^{c}$ \\
\hline & $\Gamma^{\mathrm{IE}} \mathrm{E}^{\mathrm{a})}$ & 0.062 & 0.016 & & **c) \\
\hline $50 \mathrm{ppm}^{\mathrm{d})}$ & Ashing - $\mathrm{IE}^{\mathrm{a})}$ & 0.073 & 0.014 & & \\
\hline & $L_{\text {Ashing - GC }}$ & 0.088 & 0.016 & & \\
\hline & $\Gamma^{\left.I E^{a}\right)}$ & 0.097 & 0.028 & & *c) \\
\hline $100 \mathrm{ppm}^{\mathrm{d})}$ & Ashing - IE ${ }^{a)}$ & 0.107 & 0.022 & & 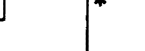 \\
\hline & $L_{\text {Ashing }-\mathrm{GC}}$ & 0.133 & 0.026 & & 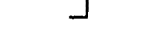 \\
\hline & $\Gamma^{\mathrm{IE}^{\mathrm{a})}}$ & 0.132 & 0.050 & & \\
\hline $200 \mathrm{ppm}^{\mathrm{d})}$ & Ashing - $I E^{a)}$ & 0.155 & 0.050 & & \\
\hline & $L_{\text {Ashing-GC }}$ & 0.177 & 0.046 & & \\
\hline
\end{tabular}

\footnotetext{
a) $: F$ ion electrode

b) : The difference between the two means is significant at the level of $\mathrm{P}<0.01(*)$ in Wilcoxon's signed rank test. ${ }^{30)}$

c) : The difference between the two means is significant at the level of $\mathrm{P}<0.01(*)$ or $\mathrm{P}<0.001(* *)$ in the Mann-Whitney $\mathrm{U}$ test. ${ }^{30)}$

d) : F concentration in drinking water in each experımental group.
}

84 90\%, CV は0.08前後であり，ここでもとくに固定 版添加の有効性は認められなかった。

\subsection{NBS 標泮試料の F 測定}

NBS の標隼試料を灰化し GC 测定した成績を Table 5 に示した。

Orchard leaves と oyster tissue のいずれにおいても 固定剤を添加して行った灰化では，NBS の参考値に対 して 86 105\%の测定値が得られた。しかし oyster tissue では固定鼡の有無が成績に大きく作用し, 無添加 のものは $1 / 10$ 以下の測定值となった。

\subsection{F 饮用ラットの血繁中 $\mathrm{F}$ 筫度}

\section{5 .1 対照群と各 $\mathrm{F}$ 投与群の平均 $\mathrm{F}$ 浱度}

無灰化一イオン電極法, 灰化一イオン電極法, 灰化一 $\mathrm{GC}$ 法で測定した $\mathrm{F}$ 飲用ラットの血洯中 $\mathrm{F}$ 浱度を各試料 について測定法別の対応をとり，その変動をFig. 5 に示 した。またその平均值について Mann-Whitney U test ${ }^{80}$ で有意差検定した結果を Table 6 に示した。

無灰化一イオン電極法の場合も TISAB III（約 $\mathrm{pH}$ 5 ) を添加しているので必ずしも生体中の free のF と 一致していないかもしれないが, ionizable F（以下本法 における無灰化一イオン電極による F測定値を ionizable F とする）と考えられ，灰化を行った後の湘定値は total F (以下灰化法による F 測定値を total F とする) に相当する。

Table 6 に示したごとく，対照群と50ppm 群，50ppm 群と100ppm 群の血策中平均 F 浱度は, Mann-Whitney U test ${ }^{300}$ の結果, 3 種の測定法のほとんどすべてにおい て, $\mathrm{P}<0.01$ の危険率で有意差が認められた。しかし $100 \mathrm{ppm}$ 群と200ppm 群の間には有意差は認められなか った。

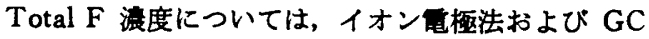
法で測定した值は，4 群すべてにおいて GC 法が高い 平均値を示し, Wilcoxon's signed rank test ${ }^{80)}$ の結果 $\mathrm{P}<0.01$ で有意差が認められた。

3.5.2 Ionizable $\mathrm{F}$ と total $\mathrm{F}$ の相関

Ionizable F とイオン電極法で測定した total F およ び ionizable F と GC 法で測定した total F との相関 保数と回㷌直線をそれぞれ Fig. 6 (1)〜（2）に示した。 GC 法, イオン電極法とも高い相関 $(r=0.95 \sim 0.97)$ が確認され， total F は ionizable F に比例していると 云える。

また total Fについてイオン画極法で測定した値と GC 法で测定した値との相関係数と回㛿直線を Fig. 7 に示した。×は0.97となり,イオン電極法と GC 法は 

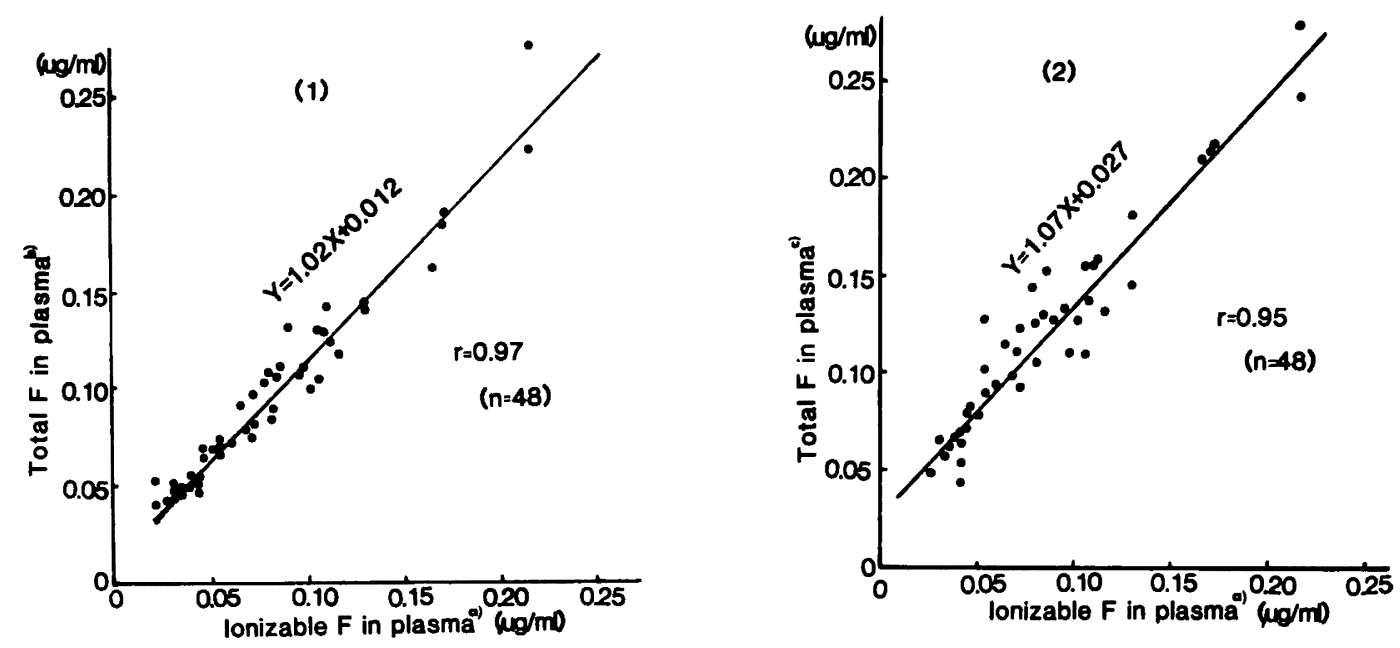

Fig. 6 Correlation of $\mathrm{F}$ values from the direct electrode method with those from two other methods

a): The value measured by $\mathrm{F}$ ion electrode without pretreatment by ashing (direct method).

b) : The value measured by $\mathrm{F}$ ion electrode after pretreatment by ashing.

c): The value measured by GC after pretreatment by ashing.

Table 7 The ratio of ionizable $F$ to total $F$ in rat plasma

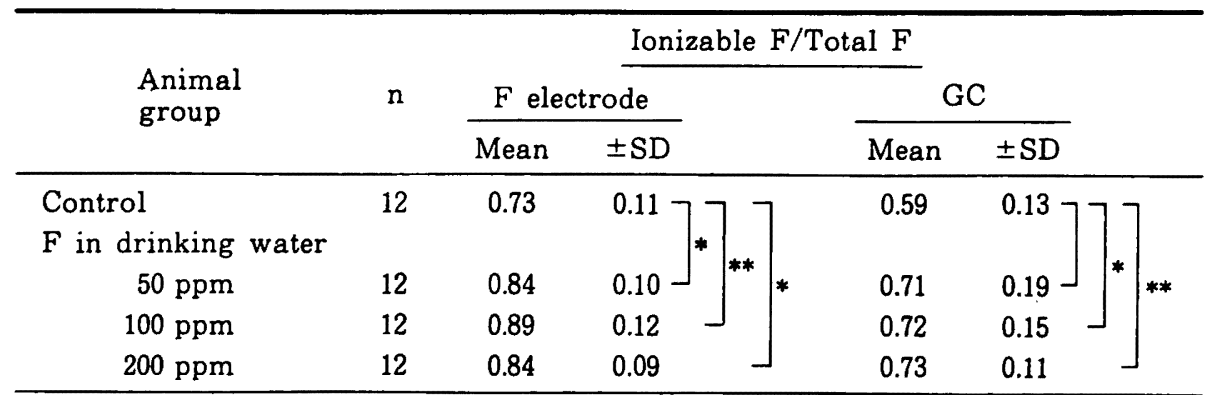

Asterisks indicate significant differences from t-test at the level of $P<0.05(*)$ and $P<0.01(* *)$.

高い相関があることが判明した。

\subsubsection{Ionizable $\mathrm{F}$ と total $\mathrm{F}$ の比率}

対照群およびF 飲用ラットの 3 群について ionizable $\mathrm{F}$ と total F の比を求めて, その平均値と $\mathrm{SD}$ を Table 7 に示した。

イオン電極法では ionizable $\mathrm{F} /$ total F の平均值は 0.73 0.89, GC 法では0.59 0.73となった。対照群の ionizable F/total F の比はイオン電極法, GC 法とも投 与群のそれらに比べて小さい值を示し, $\mathrm{t}$ 検定の結果 $\mathrm{p}<0.05$ で有意差が認められた。

\section{考察}

\section{1 前処理および測定法について}

低温酸素プラズマが分析化学の領域で最初に有勃に利 用されたのは，有機性試料を緩徐に酸化してその中の無 機成分を定量しょうとする試みであり, 以後生体試料中 微量金属元素定量への応用検討がなされている28,298。

しかし現在までF分析にこの低温灰化法を適用した報 告はみられない。そのため低温灰化時における固定棛の 必要性の有無, その選択と添加量, および低温灰化装置 の陪定条件など数多くの検璟項目があったので，本実験

に先立ち，Fを添加した無灰滤紙で基整的検討を行っ 


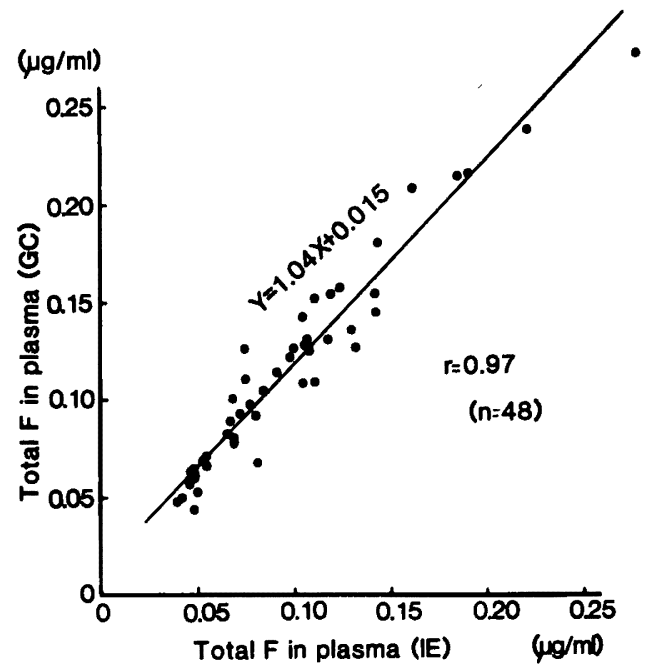

Fig. 7 Relationship between total $F$ values obtained from GC analysis and F ion electrode measurement

た。その結果，無灰滤紙に $\mathrm{F}$ 添加した場合，検討した いかなる灰化条件においてもF回収率は $0 \sim 4 \%$ であっ た。

そこで Fの固定剤を検討したところ，アルカリ土類金 属の添加により回收率が $90 \%$ に向上することが判明し た。アルカリ土類金属の中でも原子 $(\mathrm{Mg}, \mathrm{Ca}, \mathrm{Sr}) に$ よって固定効果に差が認められたので, さらに牛血清を 用いて固定郕の効果判定と選択を行ったが Table 1 K 示したように $\mathrm{MgCl}_{2}, \mathrm{CaCl}_{2}$ では灰化不良をもたらし 良好な結果は得られなかった。しかし $\mathrm{SrCl}_{2}$ では灰化が 良好に行われ94\%の回収率が得られた。しかし同時に行 った固定剤無添加の場合の回收率は $78 \%$ であり，血清に おいては適切な灰化条件を設定すれば，固定㓮無添加で も回収率を向上させられると考えられた。本法では固定 㑉を添加しないことは，固定凪からのF污染を除くばか りでなく，灰化時間の短縮につながるので大きな利点と なる。

固定片無添加で灰化条件を検討した Table 2，4 種の 測定法によるF 回收率を検討した Table 4 の結果から も，血清に扔いては固定郕無添加でも再現性の高い回収 率が得られると考える。

しかし固体試料などには，一般的に固定剤添加の必要 性があったので（Table 5)，固定剤の精製法を検討し た。

従来の灰化法においても，固定剤の添加およびその精 製については, Taves`が $\mathrm{MgCl}_{2}$ を, Ophaug と Sin- $\operatorname{ger}^{11-18)}$ が低Fリン酸カルシウム $\left[\mathrm{Cas}\left(\mathrm{PO}_{4}\right)_{2}\right]$ を用いて 検討している。また原ら ${ }^{26,27)}$ は各種の $\mathrm{Mg}$ 系， $\mathrm{Ca}$ 系 固定剤の効果について検討を加え，固定剂中の F および 灰化炉からの污染などの問題点を指摘しているが, Venkateswarlu17)も酸素ボンブ法とルツボ灰化法との比校を 行い,ルツボによる灰化時のF污染を報告している。

本法に用いた固定剂精製法は，TMCS を用いて固定 剂中のFを除去し，ブランク值が殆んど雾となるよう精 彆されているので，固定倣を多量に必要とする従来の灰 化に使用しても，低ブランク值が得られ利用価值が高い ものと考えられる。

本実験に使用した Branson/IPC 1005型低温灰化装膡 は 2 つのパイレックスガラス製灰化チャンバーがあり， 合計12コの試料を一度に灰化することができる。この各 試料を均一に灰化するためには，灰化出力と酸素流量の 比率が重要であると立われている28)。

著者らは予備実験において各出力と酸素流量比 $(0.5$, $1.0,2.0,3.0)$ による減紙の灰化率から, 出力/酸素流 量比は 1 が適正であると認めたので，血清の灰化条件検 討の際には比率1についてのみ行った（Table 2)。

$\mathrm{GC}$ 法における $\mathrm{F}$ は下記に示すように $\mathrm{pH}$ 1以下で 定量的に trimethyl silanol と反応して TMFS に誘導 される22)。

$$
\begin{aligned}
& \left(\mathrm{CH}_{3}\right)_{3} \cdot \mathrm{SiCl}+\mathrm{H}_{2} \mathrm{O} \longrightarrow\left(\mathrm{CH}_{3}\right)_{8} \cdot \mathrm{SiOH}+\mathrm{HCl} \\
& \left(\mathrm{CH}_{3}\right)_{8} \cdot \mathrm{SiOH}+\mathrm{H}^{+}+\mathrm{F}^{-} \longrightarrow\left(\mathrm{CH}_{3}\right)_{8} \cdot \mathrm{SiF}+\mathrm{H}_{2} \mathrm{O}
\end{aligned}
$$

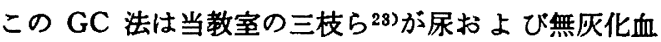
清試料について検討し発表しているが，さらに今回， TMCS 抽出時間の短縮, GC 充塔剂の変更, 絶対検量 線法の探用などを検吋し简易化した。本法は妨害イオン からの分離が可能であり, 測定感度も高いなど利点が多 い。

しかし TMFS の保持時間は約40秒であり非常に短い が，溶媒（n-hexane）流出後 GC 装固を安定させ次の 試料導入までに 15 分ぐらい必要であること，および TMFS の沸点が低いため, 常に $4^{\circ} \mathrm{C}$ 以下のところで分 析操作を行わなければならないことなど本法の今後検討 すべき点である。

次に低温灰化法と現在最も多用されているイオン電極 法との組合せは, イオンメーターの操作が単純であり, 分析法の箱易化を計るために検討を進めた。問題は灰化 試料をいかに定量的且つ最小液量に溶解するかというこ とであった。GC 法のごとく $\mathrm{HCl}$ に溶解した後, 直接 イオン電極で測定を行うことは，測定 $\mathrm{pH}$ が約 5 である 
オン電極の特性から無理であった。また一度 $\mathrm{HCl}$ で溶 解した試料をアルカリで中和しても $\mathrm{pH}$ 調製がむずかし いため，F測定値の再現性を損ら結果となった。

そこでごく少量の TISAB IIIを直接灰化ボートに添 加したところ, 灰化試料は $\mathrm{HCl}$ の場合と同様すぐ完全 に溶解し, その後10倍量の蒸留水を加えイオン電極測定 溶液とすることができた。

灰化一イオン電極法は操作が简単で検出限界も GC 法とほぼ同じレベルであり，血清・血洯の total F 測定 にも有利であると云える。

しかし $\mathrm{SrCl}_{2}$ を固定剤として添加した試料では，GC 法に比べ約 $50 \%$ 以下の低い測定值を示し，多共の存イ オンによる妨害が示唆された。これら固定鼡を添加した 試料は GC 法で測定を行らか,または hexamethyl

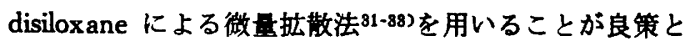
考える。

低温灰化法を F 分析の前処理に応用する本法の客䚁的 評価には, $\mathrm{NaF}$ の添加回收試験成績が一応の 目安とな るが, organic F に対応するためには不充分であり，世 界的に評価の高い NBS 標準試料の测定を行ら必要があ ると考えた。

NBS の orchard leaves と oyster tissue のF湘定値 と NBS の参考值とを比校した成䌙を Table 5 に示し たが、これは本法の固体試料への応用成續でもある。固 定剤を添加した場合は NBS の参考値に対して両者とも 86 105\%の分析値が得られた。固定剤を添加しない場 合は oyster tissue の測定值が低くなり, 固定剤添加の 必要性が認められた。

このように各試料の組成および形態の違いにより固定 猟添加の必要性が生しる理由については，おそらく有機 犋表面での酸化然焼機構が異るためと思われるが，酸素 プラズマ灰化の有機澌表面における酸化機構については あまり検討がなされておらず28)，想像の域をでない。

また固定剤添加による F 固定の機構についても解明さ れていないのが現状であるが，低温灰化法において固定 剂の添加は基本的に必須なものと考える。

Singer と Armstrong ${ }^{34)}$ はイオン電極を用いて直接血 液中 F 測定を行い, そのタンパク犋成分（アルブミン） が妨害するため再現性のよい電位差を得ることができな いと報告している。しかし本実験では無灰化一イオン電 極法により測定した ionizable F は，牛血清によるF添 加回收試験（Table 4) においても再現性のよい測定値 を与え（CV=0.01）また回収率も $98.4 \%$ と高くこのの ことは血清中タンパク犋への新たな結合がないことを示
唆している。この結果は Chiba ら ${ }^{20)}$ が $6,8,12 \% の$ フルブミンを含む人工血清中 F を測定した際, タンパク 璂により何ら影響を受けなかったと報告していることと よく一致している。

\section{2 ラットによる $\mathrm{F}$ 飲用実験について}

血清または血策中の inorganic $\mathrm{F}$ の值について, Belisle と Hagen ${ }^{19)}$ 住 ionic $\mathrm{F}$ と acid-labile $\mathrm{F}$ の両者 が含まれることを強調し, 強酸を用いない $\mathrm{F}^{-}$測定の必 要性を述べている。本報告では TISAB IIIを用いてイ オン電極で測定した值を ionizable $F$ として表現して いる。TISAB IIは約 $\mathrm{pH} 5$ に調彆されており，強酸 ではないがしかしこれを添加することにより，どの程度 acid-labile F が含まれているのかはっきりしない。

Inorganic F についてさえ，測定法により異った测定 值が得られているのが現状である。まして血清又は血鼎 中 organic F については, Taves'のアルブミンとの結合 䂱, さらに同じく Taves'10)のアルブミンに結合している より小さい分子と F との共有結合説が発表されて以来,

多くの研究者達により inorganic-organic, ionic-nonionic, exchangeable-non-exchangeable, free-bound な どの表現で血液成分中の $\mathrm{F}$ の存在様態およびその量的関 係が論じられている。

Belisle ${ }^{35}$ )は血液中 organic F の源が自然環境からか。 または産業発生源的なものによるものであるかといら問 題を提起し, Niazi と Chiou ${ }^{86)}$ は organic F の血液成 分への溶解度がひとと動物では大きく異り，また動物種 により全血で 4 倍, 血烦では33倍もの開きがあることを 報告している。Belisle と Hagen ${ }^{19)}$ も論しているごと く, 血液中に存在する organic F は, その性状により あるものはアルブミンの部分に結合し，あるものは赤血 球の部分に結合しており，血清または血漿中 organic F の割合は一定しているものではないと考えられる。

ラットのF投与実験は従来から数多く行われている が, 血液中 $\mathrm{F}$ 存在㥞式について, Ophaug と Singer ${ }^{11}$, Patterson 5 ${ }^{18)}$, Singer $と$ Armstrong ${ }^{84}$, Taves ${ }^{87}$ )らは実験検郡を行っている。

著者らのラットによるF投与実験は, 市販の牛血清で はF掫取量も不明であり，長期保存による $\mathrm{F}$ 結合様式の 変化も推定され，最適な試料とは云い難いので，Fをあ る程度含む新鮮な血液試料を得て, 低温灭化法による血 液中微量 $\mathrm{F}$ 測定の可能性を実証したいと考え行ったもの である。そのため前述したごとく，血液中 $\mathrm{F}$ の存在様式 にかかわる多くの因子を考えると動物実験として充分な ものではなく，F代謝にかかわる論述を行らことはむず 
かしいと思われる。

しかし低温灰化後 GC およびイオン電極で測定した total F と直接イオン電極で測定した ionizable F の相 関係数（r）は0.95および0.97と非常に高い值を示した。 このことは total F が ionizable F に比例しているこ とを示すばかりでなく，前処理法および両方法の分析精 度も高いことを示唆している。

また対照群およびF 飲用ラットの 3 群について求めた ionizable F と total F の比の平均值は, イオン電極法 および GC 法とも, 対照群と投与群の間には有意差が 認められている (Table 7)。すなわち対照群では, イオ ン要極法で0.73, GC 法で0.59となり, 投与群ではイオ ン電極法で0.84 0.89, GC 法で0.71〜0.73となり，投 与群の血洯中 ionizable F の割合が增加していると云え る。

ラットの血清中 organic F について Taves ${ }^{87)}$ は高莀 度のFを投与した際, 動物血液中の inorganic F の增 加は認めたが, organic F はほとんど認めなかったと報 告している。著者らの実験では $\mathrm{F}$ 投与ラットの血液中に も organic F に相当するFが認められ，Taves の結果 とは一致しない。一方 Singer と Armstrong(3)はラッ トに蒸留水および $75 \mathrm{ppm}$ の $\mathrm{F}$ 含有飲料水を与えて両群 を比較し，高漉度 F拱取群では血清中 ionized F の割 合が高くなったことを報告しており，著者らの実験結果 も同様の傾向を示していると云える。

しかし同時に低温灰化したラット血漿中 total F 䈨度 の平均值がイオン電極法と GC 法の間に僅かず有意 な差が $(P<0.01)$ あったことの原因追究，および NBS 試料により検討したとは云え， $\mathrm{F}$ 含有多有機啠試料の兏 化は酸素ボンブ法が最もよいとする Belisle と Hagen ${ }^{19)}$ の報告もあり，今後さらに organic F 測定について検 討が必要であると思われる。

また長期 $\mathrm{F}$ 接取の場合の ionizable F と total Fの比 率の変化，さらにひとへの外雨なども今後の検討すべき 課題である。

\section{結論}

多有機質中微量 $F$ 测定の前処理法として，低温酸素プ ラズマ死化の応用を試み, その灰化の条件, 固定剤添加 の必要性およびその選択などを，GC 法とイオン電極法 でF測定を行って検时し, 次の結果を得た。

1) Branson/IPC 1005 型低温灰化装圈を用いて，牛 血清 $(2 \mathrm{ml})$ を次の条件で灭化し好結果を得た（NaF 添加回收率 : 85 90\%)。固定剂無添加, 出力 $100 \mathrm{~W}$, 酸
秦流量 $100 \mathrm{~m} l / \mathrm{min}$, 灰化時間 $4 \sim 5$ 時間。

2）低温灰化した血清・血脽試料の GC 法およびイ オン電極法による F 定量限界は，それぞれ0.015 と 0.02 $\mu \mathrm{g} / \mathrm{ml}$ であった。定量限界の上からは両分析方法に大き な差はなく，またイオン電極法と GC 法の測定値は高 い相関を示した。しかし，分析操作がやや複雑ではある が，GC 法は妨害イオンからの分触が確実であるなど有 利な面が示唆された。

3) NBS 標準試料 (orchard levaves, oyster tissue) を固定剤を添加して灰化し，GC 法でF 測定を行った結 果は NBS の参考値に対して 86〜105\%の 測定值が得 られ, 固体試料への応用の可能性む確認された。

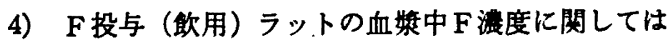
ionizable $F$ と total F か GC 法, イオン電極法とも 高い相関 ( $r=0.95 \sim 0.97)$ が確認され, total F は ionizable F に比例していると云える。また ionizable F と total F の比率はイオン電極法で0.73 0.89, GC 法 で0.59〜0.73となったが，F投与群では対照群（水道水 飲用) に比へ， ionizable F の割合が增加していること が認められた $(\mathrm{P}<0.05)$ 。

5）イオン電極および GC で測定した低温灰化血永 試料のF测定值が，両测定方法の間で僅かつつではある が有意差が認められているので，その原因追究および organic Fに対する検討がさらに必要であろう。

\section{文献}

1) Parkins, F. M., Tinanoff, N., Moutinho, M., Anstey, M. B. and Waziri, M. H. : Relationthips of human plasma fluoride and bone fluoride to age, Calcif. Tissue. Res., 16 ; 335-338, 1974.

2) Husdan, H., Vogl, R., Oreopoulos, D., Gryfe, C. and Rapoport, A.: Serum ionic fluoride: Normal range and relationship to age and sex, Clin. Chem., 22 ; 1884-1888, 1976.

3) Ekstrand, J.: A micromethod for the determination of fluoride in blood plasma and saliva, Calcif. Tissue. Res., 23 ; 225-228, 1977.

4) Ekstrand, J.: Relationship between fluoride in the drinking water and the plasma fluoride concentration in man, Caries Res., 12 ; 123127, 1978.

5) Hanhijarvi, H., Penttila, I. and Pekkarinen, A. : Human ionic plasma fluoride concentrations and age in a fluoridated community, Proc. Finn. Dent. Soc., 77 ; 211-221, 1981.

6) Hanhijarvi, H. : Ionic serum fluride concentrations and age in a low-fluoride communi ty, Proc. Finn. Dent. Soc., $77 ; 222-227$, 
1981.

7) Cowell, D. C. and Taylor, W. H. : Ionic fluoride : a study of its physiological variation in man, Ann. Clin. Biochem., $18 ; 76-83$, 1981.

8) Angmar-Mansson, B., Whitford, G. M. : Animal studies: Plasma fluoride levels and enamel fluorosis in the rat, Caries Res., 16 ; 334-339, 1982.

9) Taves, D. R.: Evidence that there are two forms of fluoride in human serum, Nature., 217 ; 1051-1051, 1968.

10) Taves, D. R. : Electrophoretic mobility of serum fluoride, Nature, 220 ; 582-583, 1968.

11) Ophaug, R. H. and Singer, L.: Influence of variations in fluoride intake on the ionic and bound fractions of plasma and muscle $f$ uoride (39736), Proc. Soc. Exp. Biol. Med., 155 ; 23-26, 1977.

12) Singer, L. and Ophaug, R. H. : Determination of fluorine in blood plasma, Anal. Chem., 49 ; 38-40, 1977.

13) Singer, L. and Ophaug, R. H. : Concentrations of ionic, total, and bound fluoride in plasma, Clin. Chem., 25 ; 523-525, 1979.

14) Ophaug, R. H. and Singer, L. : Metabolic handling of perfluorooctanoic acid in rats (40715), Proc. Soc. Exp. Biol. Med., 163 ; 19-23, 1980.

15) Venkateswarlu, P.: Reverse extraction technique for the determination of fluoride in biological materials, Anal. Chem., 46 ; 878882, 1974.

16) Venkateswarlu, P.: Sodium biphenyl method for determination of covalently bound flourine in organic compounds and biological materials, Anal. Chem., 54 ; 1132-1137, 1982.

17) Venkateswarlu, P. : Determination of total fluorine in serum and other biological materials by oxygen bomb and reverse extraction techniques, Anal. Biochem., 68 ; 512-521, 1975.

18) Patterson, C. M., Kruger, B. J. and Daley, T. J.: Differences in fluoride levels in the blood between sheep, rabbit and rat, Arch. Oral. Biol., 22 ; 419-423, 1977.

19) Belisle, J. and Hagen, D. F.: Method for the determination of the total fluorine content of whole blood, serum/plasma, and other biological samples, Anal. Biochem., 87 ; 545$555,1978$.

20) Chiba, K., Tsunoda, K., Haraguchi, H. and Fuwa, K.: Determination of fluorine in urine and blood serum by aluminum monofluoride molecular absorption spectrometry and with a fluoride ion selective electrode, Anal. Chem., 52 ; 1582-1585, 1980.

21) Ekstrand, J., Ericsson, Y. and Rosell, S. : Absence of proteinbound fluoride from human blood plasma, Arch. Oral. Biol., 22 : 229-232, 1977.

22) Munksgaard, E. C. and Bruun, C. : Determination of fluoride in superficial enamel biopsies from human teeth by means of gas chromatography, Arch. Oral. Biol., 18 ; 735-774, 1973.

23）三枝博文他：ガスクロマトグラフ法によるフッ 秦の微些定量法の検时，日街誌，34:171，1979。

24) Tsunoda, K., Fujiwara, K. and Fuwa, K. : Subnanogram fluorine determination by aluminum monofluoride molecular absorption spectrometry, Anal. Chem., 49 ; 2035-2039, 1977.

25) Tsunoda, K., Chiba, K. Haraguchi, H. and Fuwa, K. : Platinum atomic lines for determination of ultratrace fluoride by aluminum monofluoride molecular absorption spectrometry, Anal. Chem., 51 ; 2059-2061, 1979.

26）原康二他：フッ来の定青法に関する検时一兏 化を中心として一， 口腔街生会誌，30；208， 1980.

27）原 康二他：フッ秦の定量法に関する検的（II） 一灭化を中心として一， 口腔衛生会誌， 31; 295, 1981.

28）穗䖽啓一郎：低温酸素プラズマの化学とその応 用, 化学の領域, $25 ; 713-723,1971$.

29) Gleit, C. E. and Holland, W. D. : Use of electrically excited oxygen for the low temperature decomposition of organic substances, Anal. Chem., 34 ; 1454-1457, 1962.

30) Weinberg, R. and Cheuk, S. L. : Introduction to dental statistics, Noyes Medical Publications, New Jersey, 1980, p. 125, p. 128.

31) Sara, R. and Wänninen, E. : Separation and determination of fluoride by diffusion with hexamethyldisiloxane and use of a fluoride. sensitive electrode, Talanta., 22 ; 1033-1036, 1975.

32）上条啓子他：フッ素分離に书计る应散条件の検 时, 松本齿学, $4: 150-153,1978$.

33）吉田 稔他：へキサメチルシシシロキサンを用い るフッ秦の微量拡散分析法, 日本化学会誌, 10 ; 1375-1379, 1978.

34) Singer, L. and Armstrong, W. D. : Determination of fluoride in ultrafiltrates of sera, Bicochem. Med., 8 ; 415-422, 1973.

35) Belisle, J.: Organic fluorine in human serum: Natural versus industrial sources, Science., 212 : 1509-1510, 1981.

36) Naizi, S. and Chiou, W. L.: Fluorocarbon 
aerosol propellants VI : Interspecies differences in solubilities in blood and plasma and their possible implications in toxicity studies, J. Pharm. Sci., 64 ; 1538-1541, 1975.
37) Taves, D. R. : Comparison of Organic fluoride in human and nonhuman serums, J. D. Res., 50 ; 783, 1971.

\begin{abstract}
The application of a low temperature ashing system to pretreatment of biological materials for the determination of their fluorine contents, Misako TOMITA*, Shuichi SUZUKI*, Shigeru KUROIW A* and Yoshihiro KANEKO*. Low temperature oxygen plasma ashing has been an advantageous pretreatment method for the determination of some kinds of trace elements in biological materials, but it has not been reported as a pretreatment procedure for fluorine quantifica-
\end{abstract} tion.

We examined the suitability of a low temperature ashing system (BRANSON/IPC 1005-248 AN Low Temperature Asher) as pretreatment of biological materials(both solid and fluid samples) to assess their fluorine contents. Gas chromatography (GC) and a fluorine ion-selective electrode (F electrode) were used for the analysis of the fluorine content in the materials after they were pretreated by ashing.

Using calf serum and NBS standard reference materials (orchard leaves and oyster tissue), we studied the operating conditions of the ashing apparatus and the necessity for the addition of some fixatives. When a known amount of $\mathrm{NaF}$ was added to the calf serum, a good determination reproducibility with a coefficient of variation of 0.08 and recovery rates of 85 to $90 \%$ was obtained in both cases when analysis was done by GC and F electrode without any addition of fixatives. The levels of fluorine content in NBS standard reference materials analyzed by GC after being ashed were almost equal to the NBS's non-certified values but only when fixatives were added.

Walso employed the ashing method for analyzing ionizable $F$ and total $F$ in the blood plasma of rats given drinking water containing $0,50,100$ and $200 \mathrm{ppm} F$ for 10 days with the combined use of $\mathrm{GC}$ and the $\mathrm{F}$ electrode. Both ionizable and total $\mathrm{F}$ in the plasma were increased by increases of fluoride $(\mathrm{NaF})$ in the drinking water. The ionizable-to-total $\mathrm{F}$ ratio was found to be significantly higher in the blood plasma of those rats given drinking water containing over 50 ppm fluorine than in the control group. The total $F$ value obtained from the same plasma sample after being ashed was generally higher in GC analysis than in $\mathrm{F}$ electrode measurement. The reason for this difference is unclear for the moment and further elucidation of the problem will be required.

Koy words: Fluoride, Biological materials, Blood, Low-temperature ashing, Gas chromatography 